\title{
DOES EU FUNDING SUPPORT THE DEVELOPMENT OF TOURISM? CASE STUDY OF WARMIŃSKO- -MAZURSKIE VOIVODESHIP
}

\author{
JOANNA ZIELIŃSKA-SZCZEPKOWSKA, ${ }^{1}$ DONATA SAWULSKA-KAMIŃSKA ${ }^{2}$
}

University of Warmia and Mazury in Olsztyn

Faculty of Economic Sciences, Department of Economic and Regional Policy

${ }^{1}$ e-mail: joanna.zielinska@uwm.edu.pl

2e-mail: donate_21@wp.pl

\section{\begin{tabular}{l|l} 
JEL CODES & O21, O31, O43, R11, R58
\end{tabular} \\ KEYWORDS cohesion policy, EU fundings, development of tourism, tourism infrastructure}

ABSTRACT The aim of the presented article is to answer the question of whether EU funding supports the development of tourism. In order to realize this aim, the article analyses in-kind and financial support of the EU cohesion policy for the development of tourism in a selected region of Poland, accounting for the two programming periods in the years 2007-2013. The paper is divided into two basic stages. The first part contains a review of literature on the topic of EU funds for tourism available in the second programming period. The second part is based on presenting the intensiveness of the EU cohesion policy's financial support for tourism in Warmińsko-Mazurskie Voivodeship. The studies carried out reveal a relationship between investment activity and an increase in tourism traffic, measured by the number of overnight stays in the Warmińsko-Mazurskie Voivodeship.

\section{Introduction}

The development of tourism in a given area depends largely on the state of natural resources, cultural heritage, available infrastructure (including transport and accommodation), and human as well as social capital. The greatest proceeds connected with tourism characterize countries and regions that are active in this scope and whose authorities have decided to pursue continued, consequent investments in its development (Klimek, 2010). At the same time, literature on the topic 
draws attention to many examples of activities on behalf of the development of the tourism sector in peripheral regions, where properly prepared and implemented programmes may serve revitalization functions and stimulate the development of tourism (Balough, Coros, Negrea, Coros, 2010; Talaya, Mondéjar Jiménez, Mondéjar Jiménez, Meseguer Santamaría, 2010).

Regardless of the nature and level of development of a given region, the actions assumed by regional authorities focused on supporting and/or realizing investments ought to form the basis for developing its tourism offer (Butowski, 2009). Financial resources should result in investments which do, in fact, influence the tourism potential of a given region, e.g.: by improving tourism values and attractions, or increasing the quality of tourism infrastructure. Appropriate investing should lead to the establishment of unique tourism products which will facilitate preparing diverse offers of spending leisure time for tourists and, in consequence, result in a higher number of tourist visits to the region (Poon, 2009).

In the regions of the EU member states, activities focused on the development of tourism may be financed from resources derived from the European Union budget intended for the realization of cohesion policy. As stated by Halkier, the specific role of EU resources in this scope regards supporting the development of new services, especially in those parts of Europe where tourism had been, to this date, a sector of relatively lesser importance (Halkier, 2010). This view is also supported by Coles and Hall (2005), according to whom the financial support of activities assumed on behalf of the development of tourism can be the driving force behind economic-social changes, above all in countries which have recently joined the European Union (Coles, Hall,2005).

Warmińsko-Mazurskie Voivodeship is among the regions characterized by a high development potential of the tourism sector. The region possesses significant tourism and environmental values on the European level, including: an interesting landscape, countless lakes and forests, a clean natural environment, as well as cultural monuments and historical sites. At the same time, as indicated in the Regional Operational Program 'Warmińsko-Mazurskie' for 2007-2013, 'tourism remains an area of great opportunity for development of the region, not yet taken advantage of,' (Regional Operational Programme..., 2007). Studies carried out by Zielińska-Szczepkowska (2015) point out that the region possesses, above all, the potential for the development of active and cultural tourism. Such development is largely dependent on the level of basic tourism and tourismrelated infrastructure; these, however, as shown by statistical data prior to the second programming period financed by the EU, were relatively low (Local Data Bank, 2007). ${ }^{1}$

Keeping in mind the increased significance of EU cohesion policy following $2004^{2}$ in Poland, which created realistic chances for the development of investments, including those supporting the tourism economy, it was determined that there is good reason for looking into the topic of the

\footnotetext{
${ }^{1}$ To provide an example, there were four 4-star hotels and not any higher class (5-star) hotels in Warmińsko Mazurskie Voivodeship as of 2007,

${ }^{2}$ An analysis of strategic documents in the context of the tourism policy carried out on a regional level confirms that the tourism sector had particularly significant importance in EU cohesion policy in the second programming period for 2007-2013. As a result of this, the present article pertains to the analysis of financial instruments supporting the development of tourism projects in the years 2007-2013. It is worth mentioning here that in both the first (2004-2006) as well as third (2014-2020) programming periods, tourism was not treated as a priority area in any of the regional programmes.
} 
effects of projects co-financed from EU resources aimed at supporting tourism. The analysis was carried out for Warmińsko-Mazurskie Voivodeship, which in the years 2007-2013 was among the top Polish regions as far as the value of EU resources for the realization of tourism projects is concerned. The selected area is one of the most attractive tourist regions of Poland, characterized by significant environmental and cultural values, but at the same time requiring a cohesive policy and a series of intensive measures taken on behalf of improving the transportation accessibility, tourism and tourism-related infrastructure, as well as promoting the region. The study attempts to answer the following questions: 1) what share of resources in the pool allocated to regions was reserved for projects connected with the development of the tourism economy; 2) whether, and if so how, EU funds contribute to increased tourism attractiveness of Warmińsko-Mazurskie Voivodeship; 3) whether the realized projects influence an increase in the number of tourist arrivals in the analysed region.

The main aim of the present article is an attempt to establish whether European funds available in the second financial programming period for 2007-2013 stimulate the development of tourism in Warmińsko-Mazurskie Voivodeship. The following research methods were used in the work: deductive studies of literature on the topic (national and foreign) as well as programme documents and legal acts, analysis of the Local Data Bank of the Central Statistical Office of Poland, an analysis of EU support fund expenditures for carrying out projects supporting the development of the tourism sector in the analysed region, as well as an analysis of the contents of applications within the framework of ROP WM 2007-2013 ( $\mathrm{n}=157)$.

The text has been divided into a few parts. The first part presents basic information on the roles of EU cohesion policy in supporting the tourism sector in Poland. Moreover, it was determined which voivodeships indicated tourism as a priority area important to the development of the region's economy and allocated a portion of the resources available within the framework of ROP for supporting it. Presented further in the work are detailed analyses covering both the sources of financing as well as the manners of using the awarded grants for the development of tourism projects in Warmińsko-Mazurskie Voivodeship. Accounting for the data contained in the base of realized projects for programming period 2007-2013, the following were assessed: 1) how many projects connected with tourism received European Union funding, and at what level; 2) what was the value of the realized projects (what amount contributed to the development of tourism in Warmińsko-Mazurskie Voivodeship), and what it was intended for (what did the projects involve). The last part of the work focuses on the broader, indirect influence of the realized projects on the development of the tourism sector, identifying the increase in the tourism attractiveness of the region measured by the increase in the number of beds, the available hotel facilities and tourist arrivals in the Warmia and Mazury region.

\section{EU Funds Supporting the Tourism Sector in 2007-2013}

The European Union does not have a special budget, and thus separate financing instruments, completely dedicated to supporting business undertakings in the field of tourism. Despite this, 
the tourism sector makes use of financial support offered by various EU programs in individual member states (Zielińska-Szczepkowska, 2013). The most important financial instruments of the European Community, essential to realizing the economic and social cohesion policy of the EU are European funds along with the Cohesion Fund. Their task is to, among others, finance investments in infrastructure, promote sustainable development, and strengthen attractiveness, competitiveness and spatial cohesion.

In regard to the tourism sector, Regional Operational Programmes were of key importance in the second financial perspective. The analysis of ROPs of individual voivodeships showed that 14 of the 16 analysed regions regarded tourism as an important factor of socio-economic development and increased competitiveness. Nearly all regions with the exception of Opolskie and Łódzkie voivodeships identified it as a priority axis, setting aside a separate financial envelope for the realization of projects supporting the development of the tourism sector.

The amount of funds dedicated to the realization of these activities varied greatly. If we account for what part of the envelope allocated to ROP was reserved for the tourism sector, Podlaskie Voivodeship ranks first, designating as much as $16.3 \%$ of funds available in ROP for this purpose, followed by Świętokrzyskie Voivodeship, with a share of over 14\%, and Warmińsko-Mazurskie Voivodeship (12.6\%). Much more modest engagement of European funds for tourism characterized: Podkarpackie (3.1\%), Wielkopolskie (4\%), and Pomorskie as well as Kujawsko-Pomorskie (4.7\% and $4.8 \%$ respectively) voivodeships (Figure 1$)$.

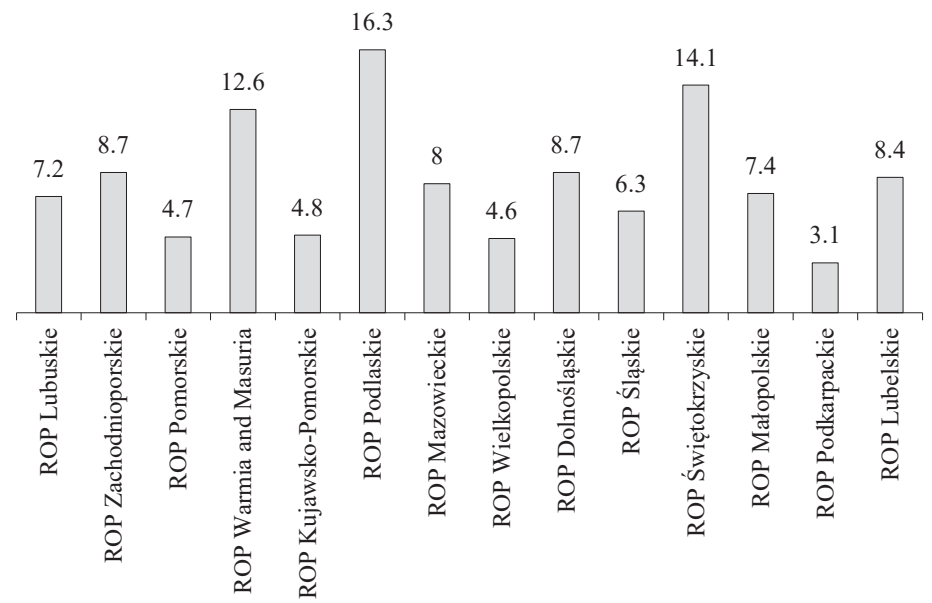

Figure 1. Percentage share of funds allocated for the priority connected with tourism under Regional Operational Programmes for 2007-2013

Source: own elaboration based on data from the Ministry of Development. Retrieved from: http://www.mapadotacji.gov.pl (1.03.2017). 
It should be emphasized that as far as value is concerned, the greatest amounts of funding for the realization of tourism projects were allocated within the framework of the ROPs of Śląskie, Mazowieckie and Warmińsko-Mazurskie voivodeships, while the least in the regional programs of: Pomorskie, Lubuskie and Podkarpackie voivodeships. Due to the differences in the initial value of budget resources allocated for the realization of ROPs in these voivodeships, this is not, however, reflected in their percentage share.

Analysing the regional operational programs of Polish voivodeships, it turns out that tourism as an independent priority appeared in Kujawsko-Pomorskie, Śląskie and Warmia-Masuria voivodeships. In regional operational programmes of the Dolnoślaskie, Lubuskie, Małopolskie, Podkarpackie, Podlaskie, Pomorskie and Wielkopolskie voivodeships, tourism was combined with culture (cultural heritage). In Zachodniopomorskie Voivodeship, it was connected with culture and the revitalization of cities, whereas in Mazowieckie Voivodeship - with recreational infrastructure. In the documents of the remaining voivodeships, it was combined with the cultural heritage and sport infrastructure (Świętokrzyskie), or interregional cooperation (Lubelskie). The tendency to connect various areas into one priority axis makes it very difficult to identify the actual share of tourism in the allocation of resources and, at the same time, impossible to explain the reason behind the existing disproportions in the allocation of resources for tourism from the ROPs of individual voivodeships (Kozak, 2010).

Based on the results of the analyses, we can moreover confirm that both voivodeships with the highest as well as lowest percentage share of resources allocated for the realization of priorities connected with tourism under ROPs for 2007-2013 were characterized by a high level of realizing so-called key projects with a similar structure of beneficiaries (above all public entities) and level of financing (from $50 \%$ in the case of projects subject to a competitive procedure, to $85 \%$ in the case of key projects). Each of the mentioned voivodeships also attributed a large role to environmental resources and natural values in the plans and strategies for the development of tourism as factors enabling the shaping and development of tourism and, in turn, the development of the entire region. As a result of the existing similarities between the voivodeships, the identification of factors influencing the diversification in the engagement of resources for tourism is more difficult.

According to Mańkowski (2014), there are no direct connections between the role of the region in managing tourist traffic in Poland and the level of allocated ROP resources for activities connected with the development of regional tourism economy (Mańkowski, 2014). Serving as an example of this is Pomorskie Voivodeship, one of the most popular tourism destinations in the country, where the extent of resources allocated to projects promoting tourism under the program is merely $4.7 \%$ of total ROP budget resources.

In addition to ROPs, it was possible to obtain financial sources for tourism-related investments from other programmes, not directly connected with tourism (Table 1). 
Table 1. Most important sources of financing the tourism sector from EU programmes in Poland in the years 2007-2013

\begin{tabular}{|c|c|c|}
\hline Programme & Priority/Measure & Examples of projects \\
\hline $\begin{array}{l}\text { OP Innovative } \\
\text { Economy }\end{array}$ & $\begin{array}{l}\text { 6.4 Investments in Tourism Products } \\
\text { of Superregional Importance }\end{array}$ & $\begin{array}{l}\text { - Restoration, modernization and management of historic } \\
\text { buildings } \\
\text { - Construction, development and renovation and modernization } \\
\text { of tourism infrastructure } \\
\text { - Management, development and modernization of post- } \\
\text { industrial and post-military buildings and areas for purposes } \\
\text { of tourism } \\
\text { - Construction and expansion of recreational and entertainment } \\
\text { infrastructure } \\
\text { - Construction and equipping of tourist information centres, } \\
\text { as well as marking tourist routes }\end{array}$ \\
\hline \multirow[t]{2}{*}{$\begin{array}{l}\text { OP Development } \\
\text { of Eastern Poland }\end{array}$} & $\begin{array}{l}\text { Measure } 2.2 \text { Congress and Trade Tourism } \\
\text { Infrastructure }\end{array}$ & $\begin{array}{l}\text { Construction, expansion and equipping of expo, trade, congress } \\
\text { and conference facilities }\end{array}$ \\
\hline & Measure 5.2 Cycle Routes & $\begin{array}{l}\text { Building and marking cycle paths and setting out and marking } \\
\text { cycle routes in extra-urban areas }\end{array}$ \\
\hline
\end{tabular}

\begin{tabular}{lll}
\hline $\begin{array}{l}\text { OP Environment } \\
\text { and Infrastructure }\end{array}$ & $\begin{array}{l}\text { Priority IV } \\
\text { Initiatives Aimed at Adjusting Enterprises } \\
\text { to the Requirements of Environmental }\end{array}$ & $\begin{array}{l}\text { Adjusting tourism enterprises (e.g. hotels) to the requirements } \\
\text { of environmental protection }\end{array}$
\end{tabular}

Protection

Priority XII

Culture and Cultural Heritage Revitalization, conservation and adaptation for cultural purposes historic building and building complexes along with their surroundings

OP Human Capital Measure 2.1. Development of Human $\quad$ Courses, including for workers of the tourism industry

Resources for Modern Economy

Measure 6.2 Support and Promotion of Resources for setting up a business, including connected Entrepreneurship and Self-employment with the provision of tourism services

Rural Development Measure 3.1 Diversification Towards Non- Support of agritourism, tourism services and services connected

$\begin{array}{lll}\text { Programme } & \text { agricultural Activities } & \text { with leisure in rural areas }\end{array}$

Source: own elaboration based on: Operational Programme Innovative Economy. Document adopted by the resolution of the Council of Ministers of 30 October 2007; Operational Programme Development of Eastern Poland. Document adopted by the decision of the European Commission of 23 December 2011 r. no. K (2011) 9789; Operational Programme Infrastructure and Environment (Version 5.0, adopted by European Commission Decision of 18 March 2016), Operational Programme Human Capital. Document adopted by resolution of the Council of Ministers on 15 January 2015; Rural Development Programme for 2007-2013, Warsaw 2013.

Finally, it is worth mentioning that a series of tourism projects of cross-border importance were also realized within the framework of European Territorial Cooperation Programmes for 2007-2013. For example, in the Warmińsko-Mazurskie Voivodeship, under the Cross-Border Cooperation Programme Lithuania-Poland 2007-2013, projects supporting the development of the tourism sector were carried out from Priority 1 (Development of Sustainable Cross-Border Tourism and Maintaining Cultural and Historic Heritage) as well as 2 (Development of New and Strengthening Existing Social and Cultural Cooperation Networks) (Zielińska-Szczepkowska, Zabielska, 2013). 


\section{Share of European Funds for the Development of Tourism - Example of Warmińsko-Mazurskie Voivodeship}

In the analysed period, all investment projects in Warmińsko-Mazurskie Voivodeship were realized from resources of the European Regional Development Fund within the framework of four operational programmes: Regional Operational Programme Warmia and Masuria (ROP WM), Operational Programme Development of Eastern Poland (OP DEP), Operational Programme Infrastructure and Environment (OP IE) and Operational Programme Innovative Economy (OP IE). Under the above-mentioned programmes, a total of 3,283 projects received financial support, with a total value of 15,471,120,414.86 PLN, of which 8,364,762,345.87 PLN came from European funds (Table 2).

Tahle 2. Absorption of funds for total investments in Warmińsko-Mazurskie Voivodeship under ERDF accounting for individual programmes in 2007-2013

\begin{tabular}{lccrc}
\hline Programme & Number of projects & Total value of investments (PLN) & EU contribution (PLN) & Own contribution (PLN) \\
\hline ROP WM & 2,850 & $9,371,789,354.27$ & $4,836,571,815.61$ & $4,535,217,538.66$ \\
OP DEP & 33 & $2,306,783,908.17$ & $1,554,403,001.86$ & $752,380,906.31$ \\
OP IE & 83 & $2,445,111,123.88$ & $1,357,611,406.74$ & $1,087,499,716.88$ \\
OP IE & 317 & $1,347,436,028.54$ & $616,176,121.40$ & $731,259,907.14$ \\
\hline Total & 3,283 & $15,471,120,414.86$ & $8,364,762,345.87$ & $7,106,358,068.99$ \\
\hline
\end{tabular}

Source: own elaboration based on data from the Ministry of Development. Retrieved from: http://www.mapadotacji.gov.pl (2.03.2017).

Taking into account the total value of the realized investments, the highest amounts of resources in the given voivodeship were allocated for projects under ROP WM for 2007-2013 (60\% of resources), while the smallest regarded projects realized under OP IE ( $9 \%$ resources).

In the programming period for 2007-2013, a total of 161 investments directly supporting the tourism sector received financial support. The total value of the investments amounted to 1,902,959,056.24 PLN, of which 834,774,954.07 PLN comprised EU grants (Table 3).

Table 3. Absorption of funds for investments in tourism in Warmińsko-Mazurskie Voivodeship under ERDF accounting for individual programmes in 2007-2013

\begin{tabular}{lcccc}
\hline \multicolumn{1}{c}{ Programme } & Number of grants & Total value of investments (PLN) & EU contribution (PLN) & Own contribution (PLN) \\
\hline ROP WM & 157 & $1,508,576,699.82$ & $637,799,640.71$ & $870,777,059.11$ \\
OP DEP & 3 & $279,382,365.42$ & $149,456,531.23$ & $129,925,834.19$ \\
OP IE & 1 & $115,000,000.00$ & $47,518,782.13$ & $67,481,217.87$ \\
OP IE & 161 & $1,902,959,065.24$ & $834,774,954.07$ & $1,068,184,111.17$ \\
\hline
\end{tabular}

Source: own elaboration based on data from the Ministry of Development. Retrieved from: http://www.mapadotacji.gov.pl (2.03.2017). 
A key programme supporting the tourism sector in Warmińsko-Mazurskie Voivodeship was the ROP WM for 2007-2013, in which the increase in the competitiveness of the economy and the number as well as quality of network connections was considered to be a priority objective (Regional Operational Programme..., 2010). Due to the fact that, in the years 2007-2013, tourism was considered to be one of the main sectors of the economy of Warmińsko-Mazurskie Voivodeship, providing income as well as workplaces, it was given special treatment, comprising a separate priority axis. The aim of the priority axis Tourism was to increase the share of tourism in the regional economy and the attractiveness of the tourism offer of the region.

Investments realized under Measure 2.1 Increase in Tourism Potential pertained to:

- the construction and modernization of tourism infrastructure - accommodation and catering base (hotels, motels, restaurants),

- sports-recreation infrastructure (e.g. swimming pools, gymnasiums, wellness centres),

- spa infrastructure (investments are carried out mainly in Gołdap as the only spa in the region is located in this city),

- public tourism infrastructure (building of cycle paths, development of beaches and lakeshores),

- buildings of cultural importance (restoration of historic buildings and modernization/construction of cultural centres - cinemas, theatres, libraries, etc.).

Under Measure 2.1, a total of 135 contracts for the realization of tourism projects amounting to 1,490,456,173.25 PLN (of which 624,051,710.19 comprised European funding) were signed (Table 4). Commune self-governments were most prevalent among the project beneficiaries, though these also included entrepreneurs as well as cultural entities and associations.

Table 4. Absorption of funds for investments directly influencing the development of tourism in WarmińskoMazurskie Voivodeship under ROP WM for 2007-2013 accounting for measures and sources of financing

\begin{tabular}{|c|c|c|c|c|}
\hline Measure & Sub-measure & $\begin{array}{l}\text { Number } \\
\text { of Projects }\end{array}$ & $\begin{array}{l}\text { Total Value of Investments } \\
\qquad(\text { PLN) }\end{array}$ & $\begin{array}{l}\text { EU Contribution } \\
(\mathrm{PLN})\end{array}$ \\
\hline \multirow{6}{*}{$\begin{array}{l}\text { 2.1. Increase in } \\
\text { Tourism Potential }\end{array}$} & 2.1.1. Restaurant and Accommodation Facilities & 44 & $557,384,055.11$ & $138,926,779.34$ \\
\hline & 2.1.2. Spa Infrastructure & 4 & $47,863,184.21$ & $38,816,987.89$ \\
\hline & 2.1.3. Sport-Recreation Infrastructure & 21 & $559,452,016.80$ & $245,779,375.34$ \\
\hline & $\begin{array}{l}\text { 2.1.4. Public Tourism and Tourism-related } \\
\text { Infrastructure }\end{array}$ & 39 & $122,766,652.35$ & $77,399,852.16$ \\
\hline & 2.1.5. Cultural Heritage & 14 & $59,219,057.51$ & $39,598,864.20$ \\
\hline & 2.1.6. Culture Infrastructure & 13 & $143,771,207.27$ & $83,529,851.26$ \\
\hline \multicolumn{5}{|l|}{$\begin{array}{l}\text { 2.2. Promotion } \\
\text { of the Voivodeship }\end{array}$} \\
\hline and its Tourist Offer & - & 22 & $18,120,526.57$ & $13,747,930.52$ \\
\hline Total & & 157 & $1,508,576,699.82$ & $637,799,640.71$ \\
\hline
\end{tabular}

Source: own elaboration based on data from the Ministry of Development. Retrieved from: http://www.mapadotacji.gov.pl (2.03.2017).

The aim of Measure 2.2 Promotion of the Voivodeship and its Tourism Offer was the promotion of the tourism values of the region of Warmia and Mazury as well as the development and 
dissemination of competitive tourism products. The measure anticipated 4 schemes according to which the realization of projects connected with the following was made possible:

1. Scheme A:

- national and international tourism promotion (including cultural) of the region and local environments, covering: the creation of promotion strategies and plans, as well as carrying out advertising campaigns, studies and marketing analyses.

2. Scheme B:

- development of a regional system of tourist reservation and information by: the construction, modernization and adaptation of already existing or newly created spaces or newly created tourism information centres or points, along with the purchase of equipment and materials.

3. Scheme C:

- projects pertaining to creating and popularizing tourism products in the country and outside of its borders by: developing concepts, publications, radio auditions, advertising spots, etc.,

- projects pertaining to the development and production of regional and local souvenirs and emblems connected with the promotion of the tourism values of the regions (visualtechnical project designs, production, etc.),

- projects within the scope of disseminating the culinary traditions of the multicultural society of Warmia and Mazury within the country and abroad by means of publications, promotional events, culinary fairs, etc.

4. Scheme D:

- projects comprising the integrated local development project titled Programme for the Development of Tourism within the Area of the Elblag Canal and Itawa Lake District.

In Measure 2.2 a total of 22 contracts were signed for financial support amounting to 18,120,526.57 PLN. The beneficiaries of the measure were commune, district and provincial self-governments, as well as organizations and associations operating on the benefit of tourism. The greatest number of projects were realized under Scheme $\mathrm{C}$ and pertained to the promotion of regional products (e.g. the Land of the Great Masurian Lakes) as well as campaigns stressing the culinary values of the Warmia and Mazury region. It is worth noting that two large investments promoted the Elbląg Canal and were based on developing new tourism offers for it. A few of the undertakings also referred to the promotion of historic and cultural values of the voivodeship (e.g. creating a multimedia guide for the historical part of Warmia).

The second programme with the highest absorption of funds for investments in tourism in Warmińsko-Mazurskie Voivodeship was Operational Programme Development of Eastern Poland (2007), encompassing an area containing 5 of the poorest voivodeships in Poland, located on the eastern border of the country, i.e.: Warmińsko-Mazurskie, Podlaskie, Świętokrzystkie, Lubelskie and Podkarpackie voivodeships. The funds allocated under OP DEP for tourism pertained to activities connected with the development of congress and trade tourism infrastructure, promoting the sustainable development of tourism as well as cycle routes. 
On the other hand, in the analysed period of time, , only one project key to the development of tourism in Warmia and Mazury received financial support under OP IE. A project involving the revitalization of the Elbląg Canal was funded under Measure 6.4 Investments in Tourism Products of Supraregional Importance. This was one of the most interesting investments making the region more attractive to tourism - a relic of hydrotechnics on an international scale and, what is more, located within a protected landscape area, neighbouring the Natura 2000 site.

\section{Influence of projects realized under ROP WM for 2007-2013 on increased tourism attractiveness}

The attractiveness of an area is in terms of tourism, decisive to its competitive advantage, comprises many factors. According to the author of the tourist motivation model, included among the 36 attributes drawing tourists to a given region, are among others: natural conditions, cultural heritage, history, tourism and tourism-related infrastructure, transportation accessibility, the image of the region, the price-quality ratio of services, public service infrastructure and the level of security (Crouch, 2007). Other authors defining the tourism attractiveness of a given destination grouped the above-mentioned factors into three elements, describing: broadly defined tourism values, transportation accessibility and accommodation (Marciszewska, 2010). Considering the scope of support of the second ROP WM 2007-2013 priority axis, the analysis of possible changes in the attractiveness of the tourism offer can be considered only in the context of the quality and availability of tourism infrastructure, which has a large influence on the decisions taken by tourists regarding their choice a given destination. Therefore, subjected to the analyses were the changes of basic indicators showing a change in the state of tourism infrastructure in the region (in a quantitative and qualitative approach). In this context, an attempt was made to analyse changes resulting from the realization of projects under ROP WM 2007-2013.

In Warmińsko-Mazurskie Voivodeship, the number of accommodation facilities increased systematically. In 2016, there were 512 such facilities, which signifies an increase of 141 (38\%) as compared to 2007 . The situation is similar in the case of year-round accommodation. Such facilities amounted to 293 in 2016, and thus increased by 95 (48\%) when compared to the base year. It is worth drawing attention to the fact that the share of year-round facilities in their total number also increased, though not so dynamically (from 53.4\% in 2007 to $57.2 \%$ in 2016) (Figure 2).

Projects co-financed under ROP WM 2007-2013 had a significant effect on increasing the number of accommodation facilities. In the framework of sub-measure 2.1.1 Restaurant and Accommodation Facilities, 44 projects were carried out, among which as many as 33 involved the construction of accommodation facilities. The value of these projects was over 500 million PLN, with financial support from EU resources of over 122 million PLN (24.5\%). Due to the fact that the majority of projects involved investments in hotel facilities which are open year-round, their impact on extending the tourist season is evident. The majority of beneficiaries also decided to develop additional services decreasing seasonal fluctuations in their establishments. These investments most often involved restaurants, conference rooms, and leisure-health as well as recreational facilities. In addition to this, the beneficiaries of a few projects emphasized the year-round availability 
of investments (e.g. the construction of year-round private apartments in Kretowiny as a means of extending the tourist season in Morąg Commune).

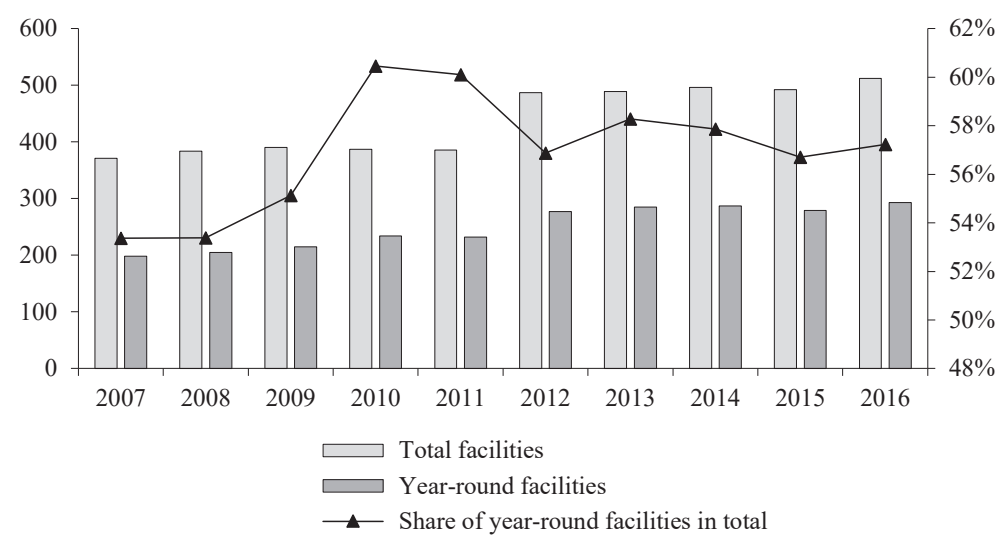

Figulp 2. Accommodation facilities accounting for total facilities and year-round facilities in WarmińskoMazurskie Voivodeship in 2007-2016

Source: own elaboration based on data from the Local Data Bank (2007-2016).

The number of beds in accommodation facilities in 2016 amounted to 40,092, thus 2,861 (7.5\%) more than in 2007. The number beds in year-round facilities increased from 19.1 thousand in the base year to 24.3 thousand in 2016 (an increase of 5.2 thousand, or 27.3\%). The share of beds in year-round accommodation in the total number of accommodation facilities showed a systematic increase from 50\% in 2007 to $59.2 \%$ in 2016 (Figure 3).

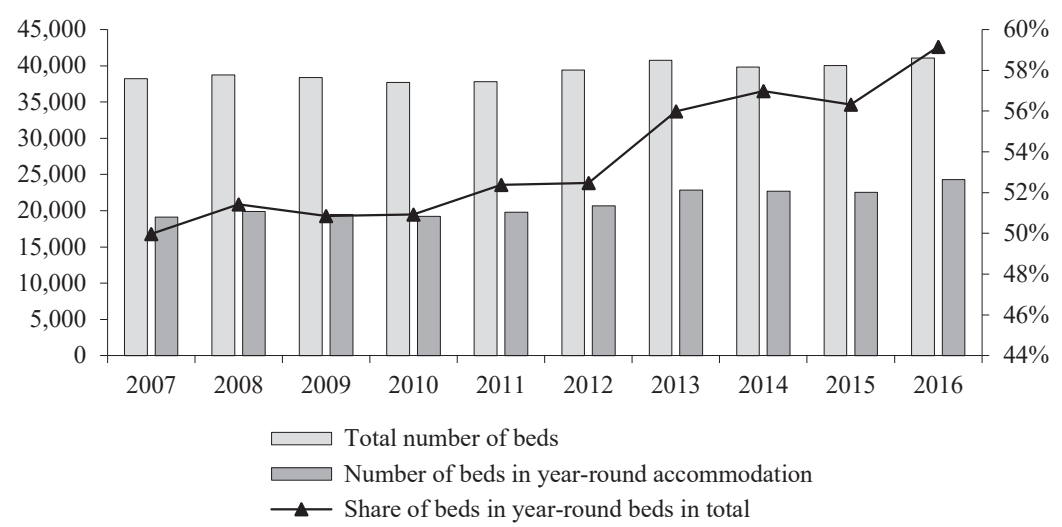

Figure 3. Beds in accommodation facilities accounting for total beds and beds in year-round accommodation in Warmińsko-Mazurskie Voivodeship in 2007-2016

Source: own elaboration based on data from the Local Data Bank (2007-2016). 
In the years 2007-2013, 7 projects aimed directly at increasing the numbers of guests that the existing facilities could accommodate for were carried out in Warmińsko-Mazurskie Voivodeship. The value of these investments was 39.7 million PLN, with financial support from EU resources comprising 32.1\% (12.7 million PLN). It is worth emphasizing that, under Submeasure 2.1.1 Restaurant and Accommodation Facilities, a total of 44 projects were carried out, of which 40 resulted in creating additional accommodation for guests. The European Union allocated a total of nearly 138.9 million PLN for co-financing projects under the mentioned EU submeasure, and as much as $97 \%$ of these resources (135 million PLN) supported the construction, expansion, modernization, retrofitting and fitting of accommodation buildings.

In the analysed time period, the number of tourists staying at accommodation facilities increased systematically (with a slight 6\% decrease noted in 2009 as compared to 2008). In 2016, nearly 1.3 million tourists visited the region of Warmia and Mazury, this being 411.6 thousand (47.4\%) more than in 2007 and 145.5 thousand (12.8\%) more than in 2015. The number of foreign tourist stays in 2016 was 160.2 thousand, and lower by 20,657 (11.4\%) than in 2007. A decrease was also observed in the share of foreign tourists in the total number of tourists staying at accommodation facilities in Warmińsko-Mazurskie Voivodeship (decrease of 8.3 percentage points). Nevertheless, the fact there were 2.6 thousand more overnight stays of tourists from abroad noted in 2016 as compared to 2015 (1.6\% increase) is promising.

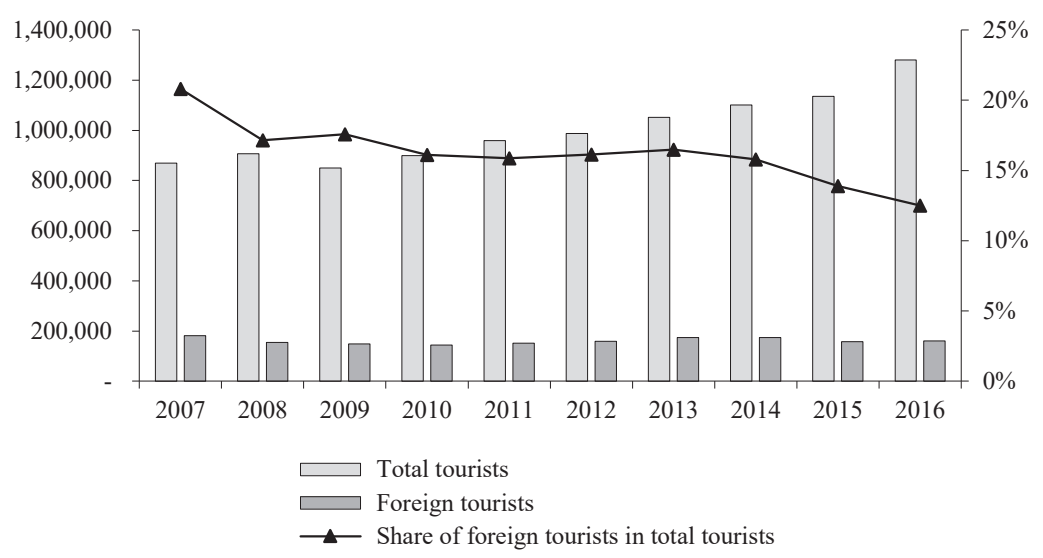

Figule 4. Tourists staying at accommodation facilities (persons) accounting for total tourists and foreign tourists in Warmińsko-Mazurskie Voivodeship in 2007-2016

Source: own elaboration based on data from the Local Data Bank (2007-2016).

In 2016, a total of 202 hotel facilities and 310 other accommodation facilities were shown to be operating in Warmińsko-Mazurskie Voivodeship. Both the number of hotel facilities as well as other accommodation facilities increased systematically; in 2016, the numbers of such facilities rose by 53 and 88 respectively as compared to 2007 (respective increases of $35.6 \%$ and 39.6\%) (Figure 5). 


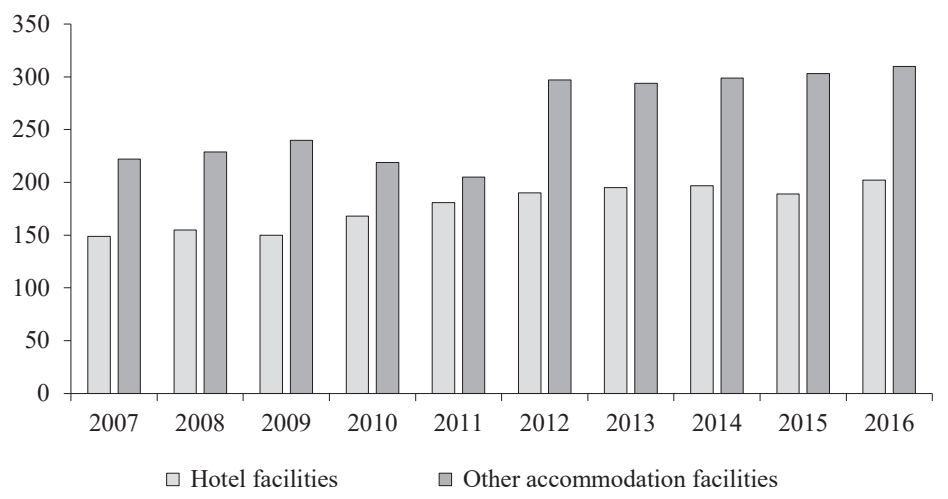

Figure 5. Accommodation facilities according to hotel facilities and other accommodation facilities in WarmińskoMazurskie Voivodeship in 2007-2016

Source: own elaboration based on data from the Local Data Bank (2007-2016).

Under Submeasure 2.1.1 Restaurant and Accommodation Facilities co-financed from RPO WM resources for 2007-2013, 25 projects involving the construction of new hotel facilities were carried out. The value of these investments was 408.3 million PLN, with EU financial support amounting to 109 million PLN (26.7\%). It should thus be highlighted that, in the years 2007-2013, nearly half of the hotel facilities in the analysed region were constructed with the engagement of European Union funds.

Among the hotels, motels and guesthouses operating in Warmińsko-Mazurskie Voivodeship, those of 3-star standard were most common, with 62 such facilities in 2016. Four- and five-star facilities were the least frequent (a total of 25). It should be noted that the number of facilities characterized by a higher standard increased dynamically, while the number of 2-star facilities did not change significantly, and the number of 1-star facilities decreased (in 2016, there were only 2 such facilities were still in operation) (Table 5).

Table 5. The number of hotels, motels and guesthouses according to category in 2007-2016

\begin{tabular}{|c|c|c|c|c|c|c|c|c|c|c|c|}
\hline \multirow{2}{*}{\multicolumn{2}{|c|}{$\begin{array}{l}\text { Number of hotels, motels and guesthouses } \\
\text { according to category }\end{array}$}} & \multicolumn{10}{|c|}{ Year } \\
\hline & & 2007 & 2008 & 2009 & 2010 & 2011 & 2012 & 2013 & 2014 & 2015 & 2016 \\
\hline & 1 & 2 & 3 & 4 & 5 & 6 & 7 & 8 & 9 & 10 & 11 \\
\hline \multirow{6}{*}{ Hotels } & category $* * * * *$ & 0 & 0 & 1 & 1 & 1 & 1 & 2 & 4 & 4 & 4 \\
\hline & category $* * * *$ & 3 & 4 & 4 & 7 & 9 & 14 & 18 & 19 & 19 & 20 \\
\hline & category $* * *$ & 36 & 37 & 37 & 40 & 43 & 40 & 41 & 41 & 43 & 53 \\
\hline & category $* *$ & 31 & 28 & 29 & 32 & 32 & 35 & 33 & 36 & 30 & 28 \\
\hline & category $*$ & 6 & 6 & 6 & 5 & 4 & 4 & 4 & 4 & 2 & 1 \\
\hline & $\begin{array}{l}\text { in the process of assigning } \\
\text { category }\end{array}$ & 11 & 13 & 16 & 10 & 8 & 7 & 9 & 6 & 7 & 7 \\
\hline
\end{tabular}




\begin{tabular}{|c|c|c|c|c|c|c|c|c|c|c|c|}
\hline & 1 & 2 & 3 & 4 & 5 & 6 & 7 & 8 & 9 & 10 & 11 \\
\hline \multirow{6}{*}{ Motels } & category $* * * * *$ & 0 & 0 & 0 & 0 & 0 & 0 & 0 & 0 & 0 & 0 \\
\hline & category $* * * *$ & 0 & 0 & 0 & 0 & 0 & 0 & 0 & 0 & 0 & 0 \\
\hline & category $* * *$ & 1 & 1 & 1 & 1 & 0 & 0 & 0 & 0 & 0 & 0 \\
\hline & category $* *$ & 3 & 3 & 3 & 2 & 2 & 2 & 2 & 2 & 2 & 2 \\
\hline & category * & 0 & 0 & 0 & 1 & 1 & 1 & 1 & 1 & 1 & 1 \\
\hline & $\begin{array}{l}\text { in the process } \\
\text { of categorization }\end{array}$ & 0 & 0 & 1 & 0 & 1 & 1 & 1 & 0 & 0 & 0 \\
\hline \multirow{7}{*}{ Guesthouses } & category $* * * * *$ & 0 & 0 & 0 & 0 & 0 & 0 & 0 & 1 & 1 & 1 \\
\hline & category $* * * *$ & 0 & 0 & 0 & 0 & 0 & 0 & 0 & 0 & 0 & 0 \\
\hline & category $* * *$ & 4 & 5 & 5 & 8 & 8 & 10 & 12 & 13 & 11 & 9 \\
\hline & category $* *$ & 7 & 7 & 8 & 6 & 6 & 5 & 5 & 4 & 4 & 5 \\
\hline & category* & 1 & 0 & 0 & 0 & 0 & 0 & 0 & 0 & 0 & 0 \\
\hline & in the process & & & & & & & & & & \\
\hline & of categorization & 11 & 10 & 9 & 12 & 13 & 12 & 11 & 10 & 11 & 11 \\
\hline
\end{tabular}

Source: own elaboration based on data from the Local Data Bank (2007-2016).

The analysis of projects carried out under ROP WM in 2007-2013 shows that EU funds supported hotels, motels and guesthouses of a higher standard of customer service. Fourteen investments aimed at constructing, expanding or increasing the standard of the discussed facilities were carried out with the engagement of EU resources ( 2 of the investments involved 5-star facilities, 11 - 4-star, and 1 - 3-star). The combined value of these investments amounted to 370.6 million PLN with the level of financial support from European resources reaching 100.8 million PLN $(27.2 \%)$. It is worth highlighting that these investments were capital-intensive, and their realization consumed $72.5 \%$ of the total resources granted to beneficiaries under this submeasure.

\section{Conclusions}

According to the EU cohesion policy for 2007-2013, tourism is among the areas significant to the development of many European regions. The analysis of ROPs of individual voivodeships revealed that nearly all regions (14 of 16) took tourism into account as an area of priority measures, thus allowing us to see the potential of this sector as an important regional development factor.

The carried out studies prove that tourism serves a significant role in the regional policy of Warmińsko-Mazurskie Voivodeship. The importance of the tourism sector was highlighted in strategic documents for 2007-2013. Under the realized EU regional policy, local authorities decided to allocate a large part of the resources to multifaceted support of the development of tourism in a region with the possibility of obtaining financial support of investment projects under ROP WM. Owing to European funds, it was possible to realize investments, such as: the development/expansion of tourism and tourism-related infrastructure (hotels, guesthouses, restaurants and buildings of cultural importance), as well as the promotion of the voivodeship and its tourist offer.

Although the assessment of the influence of European funds on the development of tourism in Warmia and Mazury is very difficult, the carried out analyses make it possible to claim that the tourism attractiveness of the region increased and will continue to increase along with further 
implementation of subsequent projects. ${ }^{3}$ The financing of investments supporting the emergence of higher-standard accommodation, the construction of sports-recreational infrastructure, and projects influencing the creation of the tourist image of the region, all of which make it possible to extend the tourism season, deserve special recognition.

In the new pool of EU resources for 2014-2020 are also funds for supporting the tourism sector. Areas within the framework of which it will be possible to obtain funding for tourism projects, such as 'Energy Efficiency', 'Natural Environment and Rational Use of Resources' and also 'Culture and Heritage', are found among the Priority axes of Warmińsko-Mazurskie Voivodeship. Additionally planned is support for creating new business models connected with packaging products and services, especially those addressed to tourist. These fit well with the no longer existing priority area 'Tourism' (Regional Operational Programme..., 2015). How much of this money is to be spent on tourism? - we will have to wait to answer this question. Besides the actual pool of available resources, even more important are regulations regarding appropriate directions of allocating resources for the realization of projects supporting the tourism sector. In line with the so-called 'domino effect' or 'snowball effect"', successful development of tourism, an increase in tourist traffic, and improved promotion of the areas of Warmińsko-Mazurskie Voivodeship that are most valuable to tourism should be reflected in the increased need for the development of tourism in other, lesser-developed, peripheral areas. The conditions present in the analysed region of Warmia and Mazury are favourable to this state of affairs.

\section{References}

Balough, M., Coros, N., Negrea, N., Coros E. (2010). The impact of European funds upon the tourism development in Macroregion One from Romania. Transylvanian Review of Administrative Sciences, 31e.

Banasik, W. (2009). Turystyka jako czynnik rozwoju lokalnego. Nowe Problemy Turystyki, 2 (3).

Butowski, L. (2009). Turystyka w polityce spójności gospodarczej i społecznej Unii Europejskiej w latach 1994-1999 i 2000-2006. Uwarunkowania teoretyczne, zakres rzeczowy, finansowy i przestrzenny. Warszawa: Wydawnictwo Difin.

Coles, T., Hall, D. (2005). Tourism and European Union enlargement. Plus ça change? International Journal of Tourism Research, 2 (27).

Crouch, G.I. (2007). Modelling destination competitiveness: a survey and analysis of the impact of competitiveness attributes. In: T. Cooperative Research Centre for Sustainable. Gold Coast, Qld.: Sustainable Tourism CRC.

Halkier, H. (2010). EU and tourism development: bark or bite? Scandinavian Journal of Hospitality and Tourism, 2 (10).

http://www.mrr.gov.pl/rozwoj_regionalny/Polityka_regionalna/Strategia_rozwoju_polski_wschodniej_do_2020/ Dokumenty/Documents/TURYSTYKA_PL_WSCH_18_10_2011.pdf.

Klimek, K. (2010). Turystyka jako czynnik społeczno-gospodarczego rozwoju Szwajcarii. Wnioski dla Polski. Kraków: Wydawnictwo PTE.

\footnotetext{
${ }^{3}$ The last agreements for the realization of projects supporting the development of the sector under ROP WM 2007-2013 were signed/annexed in the second half of 2016.

${ }^{4}$ Which were described by, among others, M.W. Kozak in an expert opinion commissioned by the Ministry of Regional Development 'Tourism as Development Factor of Regions in Eastern Poland'. Retrieved from: http://www.mir. gov.pl/rozwoj_regionalny/polityka_regionalna/strategia_rozwoju_polski_wschodniej_do_2020/dokumenty/documents/ turystyka_pl_wsch_18_10_2011.pdffhttp://www.mrr.gov.pl/rozwoj_regionalny/Polityka_regionalna/Strategia_rozwoju_ polski_wschodniej_do_2020/Dokumenty/Documents/TURYSTYKA_PL_WSCH_18_10_2011.pdf (20.04.2013).
} 
Kozak, M.W. (2010). Turystyka: niewykorzystana szansa rozwojowa regionów? Studia Regionalne i Lokalne, 4 (42).

Mańkowski, T. (2014). Turystyka w unijnych programach regionalnych. In: A. Panasiuk, (ed.), Fundusze Unii Europejskiej $w$ gospodarce turystycznej. Warszawa: Wydawnictwo Difin.

Marciszewska, B. (2010). Potencjał turystyczny regionu a kreowanie jego wizerunku. Potencjał turystyczny: Zagadnienia przestrzenne, Ekonomiczne Problemy Ustug, 52, 13-21.

Niewiadomski, K. (2009). Czynniki różnicujące ruch turystyczny na przykładzie Polski i województwa podlaskiego. Studia Regionalne i Lokalne, 4.

Poon, A. (1993). Tourism, Technology, and Competitive Strategy. Wallingford: CAB International.

Program Operacyjny Infrastruktura i Środowisko (wersja 5.0, zaakceptowana przez Komisję Europejską decyzją z 18 marca 2016 r.) (2016). Warszawa.

Program Operacyjny Kapitał Ludzki. Dokument przyjęty uchwałą przez Radę Ministrów w dniu 15 stycznia 2015 r. (2015). Warszawa.

Program Operacyjny Rozwój Polski Wschodniej. Dokument zaakceptowany decyzją Komisji Europejskiej z dnia 23 grudnia 2011 r. nr K (2011) 9789 zmieniającą decyzję Komisji z dnia 1 października 2007 r. nr K (2007) 4568 w sprawie przyjęcia Programu Operacyjnego Rozwój Polski Wschodniej 2007-2013 w ramach pomocy wspólnotowej z Europejskiego Funduszu Rozwoju Regionalnego objętego celem „konwergencja” w Polsce. Warszawa.

Program Rozwoju Obszarów Wiejskich na lata 2007-2013 (2013). Warszawa.

Regionalny Program Operacyjny Warmia i Mazury na lata 2007-2013 (2007). Olsztyn: Urząd Marszałkowski Województwa Warmińsko-Mazurskiego.

Regionalny Program Operacyjny Województwa Warmińsko-Mazurskiego na lata 2014-2020 (RPO WiM 2014-2020) (2015). Załącznik do Uchwały nr 16/150/15/V Zarządu Województwa Warmińsko-Mazurskiego z dnia 24 marca 2015 r., Olsztyn.

Szczegółowy opis osi priorytetowej „Turystyka” Regionalnego Programu Operacyjnego Warmia i Mazury na lata 20072013 (2010). Olsztyn.

Talaya, A.E., Mondéjar Jiménez, J.A., Mondéjar Jiménez, J., Meseguer Santamaría, L. (2010). La gestión del turismo en los programas de innovación rural de Castilla-La Mancha. Cuadernos de Gestión, 10, no. especial.

www.mapadotacji.gov.pl/www.mapadotacji.gov.pl.

www.mir.gov.pl/rozwoj_regionalny/polityka_regionalna/strategia_rozwoju_polski_wschodniej_do_2020/dokumenty/ documents/turystyka_pl_wsch_18_10_2011.pdf.

Zielińska-Szczepkowska, J. (2013). Polityka turystyczna. In: R. Kisiel, R. Marks-Bielska (eds.), Polityka gospodarcza (zagadnienia wybrane). Włocławek: Wydawnictwo Expol, P. Rybiński, J. Dąbek, sp.j.

Zielińska-Szczepkowska, J., Zabielska, I. (2013). Dotychczasowa diagnoza wykorzystania środków w ramach programów współpracy transgranicznej Litwa-Polska. In: Polska polityka wschodnia a współpraca zagraniczna województwa warmińsko-mazurskiego. Olsztyn: Wydawnictwo INP UWM. 


\section{CZY POLITYKA SPÓJNOŚCI UE WSPIERA ROZWÓJ TURYSTYKI? STUDIUM PRZYPADKU WOJEWÓDZTWA WARMIŃSKO-MAZURSKIEGO}

SŁOWA KLUCZOWE

STRESZCZENIE polityka spójności, fundusze europejskie, rozwój turystyki, infrastruktura turystyczna

Celem rozważań podjętych w artykule jest odpowiedź na pytanie: czy polityka spójności UE wspiera rozwój turystyki. Aby zrealizować tak postawiony cel badawczy w artykule przeanalizowano wsparcie rzeczowe oraz finansowe polityki spójności UE na rzecz rozwoju turystyki w wybranym regionie Polski, ze szczególnym uwzględnieniem II okresu programowania na lata 2007-2013. Praca została podzielona na dwa zasadnicze etapy. W pierwszej części opracowania dokonano przeglądu literatury na temat europejskiej polityki turystycznej w Polsce oraz funduszy europejskich na rzecz turystyki dostępnych w drugim okresie programowania. Druga część badań polegała na przedstawieniu intensywności wsparcia finansowego polityki spójności UE na rzecz turystyki. Za przykład posłużyło województwo warmińsko-mazurskie. Z przeprowadzonych badań wynika, że istnieje związek pomiędzy aktywnością inwestycyjną a wzrostem ruchu turystycznego, mierzonego liczbą udzielonych noclegów w województwie warmińsko-mazurskim. 